\title{
EFFICIENCY ANALYSIS OF AIRLINES USING DEA MODEL
}

\author{
Aleksandra Marcikic Horvat, Assistant Professor $^{1}$ \\ Kristina Budimcevic, $\mathrm{PhD}^{2}$
}

DOI: https://doi.org/10.31410/tmt.2018.221

\begin{abstract}
Due to deregulation and dynamic development of the air transport in the recent decades, the concept of performance evaluation and efficiency measurement has been given an increasing attention. The main goal of this paper is to use Data Envelopment Analysis to compare the efficiency of nine airlines using multiple inputs and outputs. The results of the analysis showed that Croatian Airlines, Lufthansa, Singapore Airlines and Emirates Airlines have the best ratio of the selected inputs and outputs and thus they are achieving maximum efficiency compared to the other airlines included in the analysis.
\end{abstract}

Keywords: Data Envelopment Analysis, Efficiency Analysis, Airlines

\section{INTRODUCTION}

$\mathrm{T}$

The end of the $20^{\text {th }}$ and beginning of $21^{\text {st }}$ century have been characterized by the accelerated development of the tertiary sector, i.e. the field of services. This has been evidenced by the growing share of the services in the gross domestic product, as well as the increased employment in this sector. This rapid development resulted from the numerous factors, such as: globalization, higher living standard and income, urbanization, modernization of transport, technological innovation, etc. Since the airlines business belongs to the service industry, where most of the carriers offer competitive prices and uniform loyalty programs, the only form of differentiation is the superior service quality. The modern era of globalization and technological progress has led to the growing importance of the air transport worldwide. The increased need to travel and discover new places, whether for business or leisure purposes, emphasized the role of air transport. It has led to the emergence of the "global village" concept, where people are no longer strictly tied to one place, but can afford to travel from one place to another in a relatively short time. There are close links between air transport and international tourism. The latter, in a significant way impacts on to the development and stimulation of changes in aviation and, in particular, this applies to start new routes or increasing competition by the emergence of new carriers. On the other hand, air transport is an important element of the present globalization processes and due to the growing internationalization dependencies within the global economy is open to new challenges and adapts to the needs of its users [1]. Authors [2] and [3] analyse the relationship between tourism and air transport and conclude that any changes in aviation efficiency are closely linked to tourism development. On the one hand, new forms of tourism and new destinations influence air transport demand while, airports provide essential infrastructure to support regional, social and economic growth.

The high demand for airline services led to establishment of numerous local and international carriers that are constantly seeking to find market niches, so they can stand out among the competition and sustain their business. Meeting costumers' expectations is no longer sufficient to

\footnotetext{
University of Novi Sad, Faculty of Economics Subotica, Segedinski put 9-11, 24000 Subotica, Serbia, Etihad Airways, Khalifa City A,P.O. Box 35566, Abu Dhabi, UAE
} 
keep passengers loyal to an airline. The main goal behind the high service quality is to satisfy customers' needs and create extra value for them, as only satisfied customers will return to the same company and provide a long-term source of income for them.

Due to deregulation and dynamic development of the air transport in the recent decades, the concept of performance evaluation and efficiency measurement has been given an increasing attention. The empirical studies started focusing on this topic and implementing various quantitative methods. Nowadays, there is a variety of models used in performance evaluation of the airlines with the aim to improve the quality of their service and customer satisfaction. The main goal of this paper is to implement Data Envelopment Analysis (DEA) in order to compare the efficiency of the two largest airlines in our region and seven top-ranked airlines in the world. According to [4], the non-parametric methods like DEA can help to determine the best practice when it comes to the desired performance of the organizations that operate within the same business area. Such performance evaluation is superior comparing to the traditional approaches that were emphasizing financial aspects of the business. On the other hand, the modern approaches focus on the various aspects of the business and summarize their parameters into a single measure within defined multidimensional framework.

The next chapter refers to the literature review related to this topic, while the third and fourth chapter is highlighting the development and the modern tendencies of the aviation industry. The following chapter is focused on the basic concepts of Data Envelopment Analysis that was used in order to analyze the relative efficiency of the airlines. The sixth chapter includes interpretation of the obtained DEA results, while the final chapter outlines the main conclusions and guidelines for the future research.

\section{LITERATURE REVIEW}

The feature of Data Envelopment Analysis [5] to deal with the problems involving multiple inputs and outputs, in addition to the simplicity of the assumptions underlying the model, made this method widely used in the evaluation of the air transport efficiency since 1990's. DEA method can easily be applied for the efficiency analysis in different industries, such as banking sector [6], [7], rail network efficiency in the UK [8], as well as the road transport efficiency in Norway [9].

When it comes to the airline industry, numerous authors were dealing with the operational efficiency by using different models of performance evaluation and measurement. Authors [10] implemented fuzzy logic with the aim to assess the service quality of three Taiwanese airlines, while the other study [11] applied well-known BSC method to assess the performance efficiency of the airlines in Turkey.

Schefczyk [12] used Data Envelopment Analysis in order to evaluate the airlines' operational efficiency, as well as to determine the strategic factors affecting their profitability and performance.

Yayla-Kullu and Tansitpong [13] used DEA method to evaluate and compare the performance of the low-cost and full-service carriers in the United States in terms of their service quality. 
Fethi, Jackson and Weyman-Jones [14] implemented Data Envelopment Analysis with the aim to assess the efficiency of 17 airlines over four years period. Besides that, in the second stage they applied Tobit model in order to identify the effect of various variables on the efficiency.

Rubem et al. [15] analysed the operational performance of Brazilian carriers from 2007 to 2010 using the combined approach of Data Envelopment Analysis and dynamic clusters.

In addition to the above, some of the modern studies incorporated environmental factors into efficiency analysis of the airlines. The authors [16] applied bootstrapped data envelopment analysis model with variable returns to scale in order to examine the environmental and technical efficiency of the airlines. For the purpose of the analysis, 48 world's major full- service and low-cost carriers were selected from six different regions. The obtained results showed that the most technically efficient airlines are originating from China and North Asia, while the best environmental performers are from Europe. On the other hand, another study [17] included the noise level as an undesirable output in the efficiency analysis of Taiwanese airports.

\section{DEREGULATION AND DEVELOPMENT OF GLOBAL AIRLINE INDUSTRY}

In the past decades, the aviation industry has been affected by numerous changes that have taken place as a result of rapid technological progress, changed consumer preferences and turbulent political events. Increasing demands for mobility, further globalization of society and changing consumer behaviour lead to growth in traffic flow and segmentation of the air transport industry. The deregulation of the airline industry and increasing customer awareness of service quality has added to the competitive nature of the environment.

Since US deregulation of its domestic airline markets, many countries, including the United Kingdom, New Zealand, Chile, Canada and South Africa, have deregulated or substantially liberalized their domestic markets [18]. The deregulation left significant repercussions on the development of the airline industry around the world, while liberalization and increased competition led to more sophisticated consumers' expectations in terms of the service quality. By abolishing the regulatory framework, the government has only kept control over safety, while routes, fares and the network structure were left to the market mechanism. That provided more space for business maneuvering, even though there was continued pressure from the legacy airlines to maintain the existing situation.

The rapid technological development and market changes led to a significant drop in the airlines' operating cost and further fare reduction, which resulted in the increased demand and fierce competition among the airlines. The liberalization of the air transport globally led to a „price war" among the airlines, which along with the excess capacity and increasing supply led to reduced profitability. In addition to that, the ,low cost" business concept was introduced and the Southwest Airlines was one of the first to adopt the aforementioned business model that allowed for lower air fares comparing to its competitors [19]. The advantage of these airlines is their flexibility and quick adaptation to the changing market conditions while focusing on customers' needs and satisfaction. In order to respond to the occurred market changes, the airline management started focusing more on the strategic planning, cost management and productivity enhancement, as well as customer satisfaction. 
Increasing competition, as well as the similarity of the airlines' offers, impose a significant challenge to achieve competitive advantage on the modern market. The airline network is constantly expanding and getting richer by the new destinations. The trend of globalization has contributed to the creation of strategic alliances among the airlines, which helps them increase their competitive strengths and market share, while providing passengers with superior service quality. Under these circumstances, airlines not only attempt to establish more convenient routes, but also introduce more promotional incentives, including frequent flyer membership programs and other benefits.

For a long time, the price was the key element of the marketing mix that was affecting the air carrier choice among the passengers. However, as the price is no longer the strongest tool, the emphasis is on the intensive investment in the research and development, as well as on the employee training that will deliver higher level of service quality and enable airlines to differentiate among the competition.

\section{MAIN ASPECTS OF SERVICE QUALITY IN THE AIRLINE INDUSTRY}

The exponential growth of the tertiary sector has been one of the main global market trends over the past decades. Services stimulate economic growth and generate national wealth; therefore, tertiary sector is nowadays the main contributor to the economic development.

The United States is a number one country in the services field, thanks to the increased share of the services in the gross domestic product, as well as the high employment in this sector. The same trend is evident in other developed countries, which indicates that the service sector is growing much faster than the entire global economy. This is supported by the fact that the services constitute more than a quarter of the total value of the international trade. According to Giarini [20] services are the main driving force of the economic mechanism, i.e. the natural means for satisfying needs and increasing wealth of the nation.

Every modern company within services field must be aware of the necessity for the continuous adaptation and alignment with the prevailing market trends. Competition is intensifying and it is therefore becoming more important for service organizations to differentiate their service products in the most meaningful way. The airline business is vibrant and dynamic industry since it plays a key role in the development of the world economy, tourism and related activities, by facilitating international trade and economic relations between countries and by stimulating exchange of people and ideas [18]. Airlines, as the service market leaders, must constantly monitor and follow the emerging market trends in order to timely adjust their business strategies. The primary service offered by an airline is the air transport and it is the same for all of them. However, what distinguishes them from the competition is the high quality of the service and customer satisfaction.

According to Gursoy, Chen \& Kim [21] the airlines must be able to differentiate themselves in the eyes of consumers by focusing on service quality attributes because their long-term success depends on how well they are positioned in the market place. Operational efficiency and effective marketing through understanding the consumers have already been identified as key factors in the survival and competitive success of the air carriers.

The services provided by airlines are not as complex as high technology products, but they are made up of a very complex mix of intangibles [22]. Airline products are not physical objects, but performances and experiences, thus they can differ from one service provider to another and also from one customer to another. The airline service quality is difficult to be defined and 
measured due to its heterogeneity, intangibility and inseparability. Passengers expectations and perceptions are among the factors influencing the service decisions of airlines. Thus, in order to sustain a successful business, the airlines must be aware of the fact that the basic service is no longer sufficient to secure passengers' satisfaction and loyalty, but it requires also additional services that will provide the added value for their customers.

According to Butler and Keller [23], in the airline industry it is only the customers who can truly define the service quality. Recognizing this, some air carriers tend to position themselves based on a commitment to improve the quality of customer service [10]. An airline position in relation to competitors depends on the perceptions held by users of the service, which are measured through the quality of service rendered. Service quality is an integral part of the positioning strategy since services in the airline industry are dependent on customers perceptions and expectations of the airline product. It is one of the key factors in attracting and retaining loyal customers and employees. Therefore, it is imperative for air carriers to establish a favorable image in the consumers' minds regarding their service attributes as viewed by consumers.

Empirical studies of the demand for airline services demonstrate that service quality is central to the choice of airlines for both business and leisure travelers. Delivering high-quality service to passengers is essential for the survival of airlines. According to Weber [24], what attracts customers is not a wide network of the destinations, nor their loyalty program, but the high quality of their service. This implies that the airlines must constantly work on their product and service improvement, in order to be able to successfully meet the growing demands of the passengers and ensure long term sustainability.

\section{METHODOLOGY}

Data Envelopment Analysis (DEA) is a mathematical programming technique used to analyze and compare the efficiency of different entities. Unlike parametric statistical methods, DEA compares the efficiency of each individual entity with the highest achieved level of efficiency, rather than the average. It is a non-parametric approach, since it does not require a priori assumption about the analytical form of the observed inputs and outputs. A significant advantage of DEA method is that a variety of different inputs and outputs can be used in the analysis, which can be represented by different types of metrics. The results represent the relative efficiency measures, as they depend on the number of entities involved in the analysis, as well as on number and structure of inputs and outputs. Based on the results of the analysis, it can be determined how many decision-making units (DMUs) are ineffective in relation to the effective ones, and how much it takes to reduce a certain input and / or increase a particular output in order to render these units effective. The number of DMUs which are included in the analysis depends on the research objective, as well as on the number of homogeneous units whose performance should be compared. It is recommended that the number of DMUs should be bigger than the product of inputs and outputs, to be able to effectively distinguish between the efficient and inefficient DMU [25].

There are different formulations of the linear programming models used in the DEA analysis, which have been applied in efficiency analysis of transportation industry. Based on the reviewed literature, it can be concluded that the output-oriented DEA model with a constant return to scale is the best solution when it comes to efficiency analysis of the airlines. This model was first introduced in 1978 by Charnes, Cooper and Rhodes. The analysis is carried out by solving the following model [5] of linear programming for each entity: 


$$
\begin{aligned}
& \max \Phi_{k}+\varepsilon \sum_{r=1}^{s} s_{r}+\varepsilon \sum_{i=1}^{m} s_{i} \\
& \Phi_{k} y_{r k}-\sum_{j=1}^{n} y_{r j} \lambda j+s_{r}=0 \quad r=1 \ldots s \\
& x_{i k}-\sum_{r=1}^{n} x_{i j} \lambda j-s_{i}=0, \quad i=1 \ldots m \\
& \lambda j, s_{r}, s_{i} \geq 0, j=1 \ldots n
\end{aligned}
$$

where $s$ are outputs and $m$ inputs, $y_{r k}$ is the amount of output $r$ used by DMU $k, x_{i k}$ is the amount of input $i$ used by DMU $k$ and $s_{r}$ are $s_{i}$ the output and input slacks, respectively. Efficiency of DMU $k$ is $\Phi_{k}$

\section{RESULTS}

In reference to the above-mentioned linear programming model, the data envelopment analysis will be performed in order to compare the efficiency of the chosen airlines. In order to compare efficiencies of two major airlines in our region with the world's top ranked seven airlines, the total of nine airlines were included in the analysis: Air Serbia, Croatian Airlines, Singapore Airlines, Lufthansa, KLM, Qatar Airways, Etihad Airways, Cathay Pacific and Emirates.

\begin{tabular}{|l|c|c|}
\hline Airlines & Number of passengers & Cargo transport (tons) \\
\hline KLM & 30399000 & 635590 \\
\hline Cathay Pacific & 34300000 & 1854000 \\
\hline Emirates & 51900000 & 2510000 \\
\hline Etihad Airways & 18500000 & 592700 \\
\hline Qatar Airways & 26654000 & 954191 \\
\hline Air Serbia & 2620000 & 4900 \\
\hline Croatian Airlines & 1940000 & 2591 \\
\hline Singapore Airlines & 18990166 & 1248100 \\
\hline Lufthansa & 62418000 & 1600000 \\
\hline
\end{tabular}

Table 1: Output variables of DEA model

\begin{tabular}{|l|c|c|c|}
\hline Airlines & $\begin{array}{c}\text { Number } \\
\text { of employees }\end{array}$ & Fleet size & $\begin{array}{c}\text { Number } \\
\text { of destinations }\end{array}$ \\
\hline KLM & 30002 & 203 & 148 \\
\hline Cathay Pacific & 33800 & 202 & 181 \\
\hline Emirates & 61205 & 260 & 144 \\
\hline Etihad Airways & 26635 & 122 & 112 \\
\hline Qatar Airways & 31000 & 192 & 150 \\
\hline Air Serbia & 2316 & 21 & 42 \\
\hline Croatian Airlines & 967 & 12 & 38 \\
\hline Singapore Airlines & 14046 & 106 & 61 \\
\hline Lufthansa & 34654 & 350 & 203 \\
\hline
\end{tabular}

Table 2: Input variables of DEA model 
The adequate selection of inputs and outputs is a crucial step in every efficiency analysis. This study seeks to evaluate the operational performance of the above-mentioned airlines in terms of the carried passengers and cargo tonnage, which represent the output values, while the input variables are: number of employees, fleet size and number of destinations. The data were collected from the official web sites, i.e. annual reports of the mentioned airlines for 2016. The tables 1 and 2 show the chosen output and input variables.

The Open Source DEA software has been used to perform the analysis. The presented linear programming model (1) has been solved for every DMU, thus the productivity of a company is evaluated by comparing the amount of output produced against the inputs used. The performance of each DMU is obtained by comparing its efficiency with the highest performed unit in the given data set and it calculated using a linear optimization process which tries to maximize each entity's ratio by finding the best set of weight for this particular entity [26]. The obtained results of the Output oriented CCR DEA model with constant return on scale are presented in the following tables.

\begin{tabular}{|l|c|c|}
\hline Airlines & Objective Value & Efficient \\
\hline KLM & 0.81 & \\
\hline Cathay Pacific & 0.91 & Yes \\
\hline Emirates & 1.00 & \\
\hline Etihad Airways & 0.77 & \\
\hline Qatar Airways & 0.74 & Yes \\
\hline Air Serbia & 0.69 & Yes \\
\hline Croatian Airlines & 1.00 & Yes \\
\hline Singapore Airlines & 1.00 & \\
\hline Lufthansa & 1.00 & \\
\hline
\end{tabular}

Table 3: Efficiency scores of DEA model

The results showed that four of nine observed airlines have achieved the maximum efficiency that equals 1. Accordingly, it can be concluded that Emirates, Croatian Airlines, Singapore Airlines and Lufthansa are using their resources in the most efficient way, thus achieving the optimum input-output ratio. Based on the presented results of the DEA model, it can be concluded that KLM, Cathay Pacific, Etihad Airways, Qatar Airways and Air Serbia have lower efficiency compared to other observed airlines, which means that the actual amount of inputs should give higher level of output in order to achieve the optimal efficiency.

\begin{tabular}{|l|l|}
\hline Airlines & Peer Group \\
\hline KLM & Emirates, Lufthansa \\
\hline Cathay Pacific & Emirates, Singapore Airlines, Lufthansa \\
\hline Emirates & Emirates, Singapore Airlines \\
\hline Etihad Airways & Emirates, Lufthansa \\
\hline Qatar Airways & Emirates, Lufthansa \\
\hline Air Serbia & Emirates, Lufthansa \\
\hline Croatian Airlines & Croatian Airlines \\
\hline Singapore Airlines & Singapore Airlines \\
\hline Lufthansa & Lufthansa \\
\hline
\end{tabular}

Table 4: Peer Groups

Data Efficiency Analysis is a very powerful method because it also provides information on how relative efficiency can be improved. In solving each linear model (1) the solution technique will attempt to make the efficiency of the target DMU as large as possible. This search proce- 
dure will terminate when either the efficiency of the target DMU or the efficiency of one or more other DMUs hits the upper limit of 1. Therefore, for an inefficient DMU at least one other DMU will be efficient with the target DMU's set of weights. These efficient DMUs are known as the peer group (or reference set) for the inefficient DMU [26]. Peer groups for our inefficient airlines are shown in table 4 and corresponding values of lambda are presented in table 5.

The next table shows the projections of input and output variables used in the model. Those projections will represent the guidelines for the airline management on how to improve their efficiency. For example, if we compare original input and output data for Air Serbia, we can see that number of passengers and carried cargo should be increased for 1162016.34 and 99922.43 tons respectively in order to obtain the relative efficiency score of 1 . In addition to that, the number of destinations should be decreased.

\begin{tabular}{|l|c|c|c|c|}
\hline Airlines & Emirates & $\begin{array}{c}\text { Croatian } \\
\text { Airlines }\end{array}$ & $\begin{array}{c}\text { Singapore } \\
\text { Airlines }\end{array}$ & Lufthansa \\
\hline KLM & 0.28 & 0.00 & 0.00 & 0.37 \\
\hline Cathay Pacific & 0.29 & 0.00 & 0.95 & 0.07 \\
\hline Emirates & 1.00 & 0.00 & 0.00 & 0.00 \\
\hline Etihad Airways & 0.41 & 0.00 & 0.00 & 0.04 \\
\hline Qatar Airways & 0.34 & 0.00 & 0.00 & 0.30 \\
\hline Air Serbia & 0.01 & 0.00 & 0.00 & 0.06 \\
\hline Croatian Airlines & 0.00 & 1.00 & 0.00 & 0.00 \\
\hline Singapore Airlines & 0.00 & 0.00 & 1.00 & 0.00 \\
\hline Lufthansa & 0.00 & 0.00 & 0.00 & 1.00 \\
\hline
\end{tabular}

Table 5: Lambda values of DEA model

\begin{tabular}{|l|r|r|r|r|r|}
\hline Airlines & $\begin{array}{c}\text { Number of } \\
\text { employees }\end{array}$ & $\begin{array}{c}\text { Number of } \\
\text { passengers }\end{array}$ & $\begin{array}{c}\text { Cargo } \\
\text { transport }\end{array}$ & Fleet size & $\begin{array}{c}\text { Number of } \\
\text { destinations }\end{array}$ \\
\hline KLM & 30002.00 & 37747332.47 & 1297005.52 & 203.00 & 115.84 \\
\hline Cathay Pacific & 33800.00 & 37731212.10 & 2039465.52 & 202.00 & 114.71 \\
\hline Emirates & 61205.00 & 51900000.00 & 2510000.00 & 260.00 & 144.00 \\
\hline Etihad Airways & 26635.00 & 24027915.27 & 1100102.69 & 122.00 & 67.97 \\
\hline Qatar Airways & 31000.00 & 36111231.19 & 1324492.78 & 192.00 & 109.06 \\
\hline Air Serbia & 2316.00 & 3782016.34 & 104822.43 & 21.00 & 12.13 \\
\hline Croatian Airlines & 967.00 & 1940000.00 & 2591.00 & 12.00 & 38.00 \\
\hline Singapore Airlines & 14046.00 & 18990166.00 & 1248100.00 & 106.00 & 61.00 \\
\hline Lufthansa & 34654.00 & 62418000.00 & 1600000.00 & 350.00 & 203.00 \\
\hline
\end{tabular}

Table 6: Projections of DEA model

\begin{tabular}{|l|c|c|c|c|c|}
\hline Airlines & $\begin{array}{c}\text { Number of } \\
\text { employees }\end{array}$ & $\begin{array}{c}\text { Number of } \\
\text { passengers }\end{array}$ & $\begin{array}{c}\text { Cargo } \\
\text { transport }\end{array}$ & Fleet size & $\begin{array}{c}\text { Number of } \\
\text { destinations }\end{array}$ \\
\hline KLM & 0.00 & 0.00 & 507774.72 & 0.00 & 32.16 \\
\hline Cathay Pacific & 0.00 & 0.00 & 0.00 & 0.00 & 66.29 \\
\hline Emirates & 0.00 & 0.00 & 0.00 & 0.00 & 0.00 \\
\hline Etihad Airways & 0.00 & 0.00 & 330300.24 & 0.00 & 44.03 \\
\hline Qatar Airways & 0.00 & 0.00 & 31740.78 & 0.00 & 40.94 \\
\hline Air Serbia & 0.00 & 0.00 & 97749.20 & 0.00 & 29.87 \\
\hline Croatian Airlines & 0.00 & 0.00 & 0.00 & 0.00 & 0.00 \\
\hline Singapore Airlines & 0.00 & 0.00 & 0.00 & 0.00 & 0.00 \\
\hline Lufthansa & 0.00 & 0.00 & 0.00 & 0.00 & 0.00 \\
\hline
\end{tabular}

Table 7: Slacks of DEA model 
DEA model also provides information on slacks, i.e. the potential improvements in input and output variables for the inefficient units within the given data set when compared to their efficient targets. The slacks relate to the further increases in output or reduction in input that could be gained beyond the ones implied by the radial projection. From the data presented in table 7, we can conclude that KLM, Etihad Airways, Qatar Airways and Air Serbia should be focused to improve their cargo efficiency in order to accomplish the maximum relative efficiency. Also, the number of destinations should be reduced for those inefficient companies.

\section{CONCLUSION}

Air transport link with tourism have always been noticeable. There is no doubt that the future development of the tourism industry depends on a gradual increase in air services [1]. The main goal of this paper was to assess the efficiency of the two airlines of this region with the world's top ranked airlines by using simple and powerful mathematical tool. According to the obtained results of the analysis, the Croatian airlines obtained the maximum relative efficiency, while Air Serbia should improve its efficiency by increasing the number of passengers and amount of carried cargo. The results of the performed analysis can be used as a future guideline for creating effective business strategies that will enable airlines competitiveness and sustainability on the market.

It is important to highlight that data envelopment analysis observes the efficiency of one carrier in relation to the others included in the analysis. Bearing in mind that it indicates the relative efficiency, the results of the analysis largely depend on the chosen sample. For the purpose of the future analysis, it would be interesting to observe the changes in the relative efficiency of these airlines over a longer period of time, in order to perceive the potential global trends and changes. Besides that, it would be also interesting to include the environmental factors in the future analysis.

\section{REFERENCES}

[1] Zajac G. (2016). The Role of Air Transport in the Development of International Tourism. Journal of International Trade, Logistics and Law. Vol. 2 (1). pp. 1-8.

[2] Bieger. T. Wittmer. A. (2006). Air transport and tourism-Perspectives and challenges for destinations, airlines and governments. Journal of Air Transport Management. Vol. 12. pp. $40-46$.

[3] Dimitrou D. (2018) Comparative evaluation of airports productivity towards tourism development, Cogent Business \& Management, Vol. 5.

[4] Banker. R. D. Cummins. D. Klumpes. P. (2010) Performance Measurement in the Financial Services Sector. Journal of Banking \& Finance. Vol. 34 (7). pp. 1413-1728.

[5] Charnes. A. Cooper. W. W. Rhodes E. (1978) Measuring the efficiency of decision-making units. European Journal of Operational Research. Vol. 2 (6). pp. 429-444.

[6] Paradi. J. C. Schaffnit. C. (2004) Commercial branch performance evaluation and results communication in a Canadian bank-- a DEA application. European Journal of Operational Research. Vol. 156 (3). pp. 719-735.

[7] Asaftei. G. Kumbhakar. C. S. (2008) Regulation and efficiency in transition: the case of Romanian banks. Journal of Regulatory Economics. Vol. 33. pp. 253-282.

[8] Kennedy. J. Smith. A.S.J. (2004) Assessing the efficient cost of sustaining Britain's rail 
network - perspectives based on zonal comparisons. Journal of Transport Economics and Policy. Vol. 38 (1). pp. 17-23.

[9] Odeck. J. Alkadi. A. (2004) The performance of subsidized urban and rural public bus operators: Empirical evidence from Norway. Annals of Regional Science. Vol. 38 (3). pp. 413-431.

[10] Tsaur. S.H. Chang. T.Y. Yen. C.H. (2002) The evaluation of airline service quality by fuzzy MCDM. Tourism Management. Vol. 23. pp. 107-115.

[11] Erdogan. D. Ergun. K. (2014) Understanding Performance Indicators of Organizational Achievement in Turkish Airline Companies. Journal of Management Research. Vol. 6 (4). pp. 109-123.

[12] Schefczyk. M. (1993) Operational performance of airlines: an extension of traditional measurement paradigms. Strategic Management Journal. 14. pp. 301-317.

[13] Yayla-Kullu. H.M. Tansitpong. P. (2013) A Critical Evaluation of U.S. Airlines' Service Quality Performance: Lower Costs vs. Satisfied Customers. Journal of Management and Strategy. Vol. 4 (4). pp. 1-15.

[14] Fethi. M. Jackson. P. Weyman-Jones. T. (2000) Measuring the Efficiency of European Airlines: An Application of DEA and Tobit Analysis. Leicester. University of Leicester Efficiency and Productivity Research Unit.

[15] Rubem. A. Soares De Mello. J. Angulomeza. L. Gomes Jr. S. (2017) An Analysis of Airlines Efficiency Using a DEA Model and Dynamic Clusters. Revista Espacios. Vol. 38 (37). pp. 17-29.

[16] Arjomandi. A.. Seufert. J. (2014) An evaluation of the world's major airlines' technical and environmental performance. Economic Modelling. Vol. 41. pp. 133-144.

[17] Yu. M.M. (2004) Measuring physical efficiency of domestic airports in Taiwan with undesirable outputs and environmental factors. Journal of Air Transport Management. Vol. 10 (5). pp. 295-303.

[18] Oum. T.H. Yu. C. (1999) Winning airlines: productivity and cost competitiveness of the world's major airlines. Boston: Kluwer Academic.

[19] Al-Sayeh. K. (2014) The Rise of the Emerging Middle East Carriers: Outlook and Implications for the Global Airline Industry. Massachusetts Institute of Technology.

[20] Giarini. O. (1990) Introduction: The Opportunities of the Four Pillars' Strategy. Geneva Papers on Risk and Insurance. Issues and Practice. pp. 95-99.

[21] Gursoy. D. Chen. M.H. Kim. H.J. (2005) The US airlines relative positioning based on attributes of service quality. Journal of Tourism Management. Vol. 26. pp. 57-67.

[22] Mazanec. J.A. (1995) Positioning with self-organizing maps: an exploratory study on luxury hotels. The Cornell Hotel and Restaurant Administration Quarterly. Vol. 36 (6). pp. 80-95.

[23] Butler. G.F. Keller. M.R. (1992) The cost-constrained global airline industry environment: what is quality? Transportation Quarterly. Vol. 46 (4). pp. 599-618.

[24] Weber. K. (2005) Travelers' perceptions of airline alliance benefits and performance. Journal of Travel Research. Vol. 43(3). pp. 257-265.

[25] Mimović. P. Krstić. A. (2016) Integrisana primena metoda analitičkog hijerarhijskog procesa $i$ analize obavijanja podataka $u$ vrednovanju performansi visokog obrazovanja $u$ Republici Srbiji. Ekonomski horizonti. Vol. 18 (1). pp. 71-85.

[26] http://opensourcedea.org (10.11.2018.) 